Historia Slavorum Occidentis

2021, nr 3 (30)

ISSN 2084-1213

DOI: $10.15804 /$ hso210313

Waldemar Łazuga (Poznań)

ORCID: 0000-0001-6693-7849

\title{
Oblicza tożsamości Andrzeja Szeptyckiego (1865-1944) w świetle książki Magdaleny Nowak Dwa światy. Zagadnienie identyfikacji narodowej Andrzeja Szeptyckiego w latach 1865-1914, Wydawnictwo Uniwersytetu Gdańskiego, Gdańsk 2018, ss. 613
}

Władyka świętojurski - ukraiński patriota czy polski renegat? Magnat, który wiedziony kaprysem sam się zdegradował, czy człowiek, który zmienił narodowość i kosztem osobistych wyrzeczeń poświęcił się wzniosłej misji? Polak, Rusin (Ukrainiec) czy Austriak lub - na obszarze c.k. monarchii występowała jeszcze jedna kategoria identyfikacyjna - „Rzymianin”?

Napisano już o nim bardzo dużo. Dytyrambicznie i krytycznie. Mamy biografie, monografie i wydawnictwa źródłowe poświęcone jego osobie. Sporo różnojęzycznych przyczynków. Kilkanaście pomniejszych opracowań pióra Magdaleny Nowak (autorki hasła w Polskim Słowniku Biograficznym) ${ }^{1}$. Internet pełen jest informacji o jego życiu i działalności. W środowisku badaczy historii Galicji kilku narodowości jest postacią dobrze znaną. I jedną z tych, nie tak znowu licznych, o których ma się na ogół mniej lub bardziej wyrobione zdanie (w każdym zaś razie mieć je wypada). Wciąż fascynuje: kim był Andrzej Szeptycki - syn hrabiego Jana Kantego

\footnotetext{
1 M. Nowak, Szeptycki Roman, w zakonie Andrzej, [w:] PSB, t. 48/2, Warszawa-Kraków 2012, s. 216-224. Ta sama autorka opracowała dla Słownika także biogram: Szeptycka Zofia i wespół z S. Stępniem hasło: Szeptycki Jan Kanty.
} 
Remigiusza Szeptyckiego i Zofii z Fredrów Szeptyckiej - człowiek, którego nazwisko widniało pośród magnatów w „Almanachu błękitnym”. Wnuk komediopisarza Aleksandra Fredry, wychowanek ultrakonserwatysty krakowskiego Pawła Popiela i kilku znanych jezuitów, przedstawiciel galicyjskiej elity i rodzony brat Stanisława, który w Drugiej Rzeczypospolitej był generałem broni Wojska Polskiego i ministrem spraw wojskowych. Czy identyfikacja narodowa (a właściwie autoidentyfikacja), jaka się w nim dokonała, to proces przechodzenia od polskości do ukraińskości czy jednorazowy akt „iluminacji” - „odejście od jednego systemu wartości i przyjęcie innego" ${ }^{2}$. Czy było ono ostateczne - stabilne czy labilne? Jak - i ewentualnie, w jakich proporcjach i okolicznościach - oba te światy, kultury i tożsamości, ze sobą godził? Ile w tej narodowościowej „konwersji” znaczyło wyznanie, przejście z katolicyzmu na grekokatolicyzm? Ile wzgląd na osobistą karierę? Ile ważył wpływ jezuitów z jego najbliższego otoczenia, pragnących nie tylko utrzymać kontrolę nad grekokatolicyzmem, ale i dokonać jego głębokiej reformy? Ile pamięć o odległych przodkach z Rusi Czerwonej? Ile o trzech biskupach greckokatolickich z jego rodziny, którzy w XVIII w. przyczynili się do powstania katedry św. Jura? Ile wrażliwość na różnorodne zjawiska zwane ogólnie „renesansem ruskim”? Ile syndrom gente Rutheni, natione Poloni (i związane z tym, genealogiczne i psychologiczne „powroty do źródeł”)? Ile wreszcie - idąc jeszcze dalej - bunt przeciwko despotycznemu ojcu, który rozumem nie zachwycał, a na wieść o planach ukraińskich syna skoczył „jak piorunem rażony, jak od żmii ukąszony"3. Matka - co zrozumiałe - akcentowała idealistyczne pobudki tej decyzji i stawała w jego obronie. Ojciec, świeżo upieczony hrabia, dumny z tego wyniesienia i awansu w kręgach polskiej arystokracji (gdy żenił się z Fredrówną w prezencie ślubnym otrzymał od słynnego teścia krzesło) do planów i sentymentów syna odnosił się z rezerwą.

„Casus” Andrzeja Szeptyckiego prowokuje do postawienia wielu pytań - o stosunki polsko-ukraińskie na górze i na dole, o kondycję grekokatolicyzmu i rolę w nim jezuitów (zwłaszcza w reformie bazylianów), o oblicze (i meandry) galicyjskiej oraz austriackiej polityki. A pośrednio o pojemność określenia „prawdziwa austriacka mieszanka” odnoszonego do pewnej, niemałej kategorii mieszkańców „Kakanii” - wspólnoty poliglotycznej, liberalno-demokratycznej i granic występowania tej „mieszanki” na Ukrainie. Dla wielu najważniejsze zapewne jest „drugie dno”;

\footnotetext{
2 A. Kłoskowska, Kultury narodowe u korzeni, Warszawa 1996, s. 142.

3 Zofia z Fredrów Szeptycka, Młodość i powołanie ojca Romana Andrzeja Szeptyckiego zakonu św. Bazylego Wielkiego opowiedziane przez matkę jego 1865-1892, oprac. B. Zakrzewski, Wrocław 1993, s. 54.
} 
kogo mianowicie - implicite lub explicite - Szeptycki „zdradził” i czy jeśli zdradził, to „tylko" narodowość czy także stan społeczny, środowisko, wychowanie, dom, przyjaciół etc.? Czy stał się „szczerym” Ukraińcem i tym samym innym człowiekiem, czy tylko odgrywał pewną rolę? Czy było to przeobrażenie wewnętrzne czy zewnętrzne, autentyczne czy pozorne? Motyw „zdrady”, mimo upływu lat, pobrzmiewa właściwie do dziś. Przywykliśmy bowiem do tego, że jest się Litwinem, Polakiem, Niemcem, Francuzem lub Włochem, (czemu pośrednio sprzyjają rozmaite ujęcia „tożsamościowe”) niż że jest się kimś „pół na pół” lub w jeszcze mniejszych porcjach. Do świadectw o dwóch „duszach” i dwóch ( lub kilku) kulturach w jednym od czasów Romana Dmowskiego podchodzimy z rezerwą. Materia jest specjalnie wrażliwa. I nasuwa kłopotliwe analogie. Kim bowiem byli bracia Narutowiczowie, Gabriel i Stanisław (Kazimierz Narutowicz, bratanek prezydenta mieszkający po II wojnie światowej w Poznaniu deklarowal, że jest „najpierw Żmudzinem ze świętej Żmudzi, a potem to już bywało rozmaicie” ${ }^{4}$. Kim był urodzony na pruskim Pomorzu Rudolf Virchow (twierdził, że pierwotna wersja jego nazwiska brzmiała: Wiercho), autor pojęcia Kulturkampf i przeciwnik Bismarcka na liberalnym skrzydle? ${ }^{5}$ Kim von Thadenowie z pomorskiego Triglaf - Pomorzanami i protestantami (pietystami), którzy nigdy nie zaakceptowali Adolfa Hitlera, co w 1945 r. prawdopodobnie uratowało im życie. Ludźmi pewnej religii, a nie narodu, co jest zresztą osobną kategorią? ${ }^{6}$ Kim Krokowscy (von Krockow) z Krokowej na Kaszubach, gdzie w pałacu na ścianie wiszą obok siebie portrety dwóch braci - jednego w mundurze Wojska Polskiego, drugiego w mundurze Wehrmachtu? Kim wreszcie arystokratka szwedzka o odległych korzeniach czeskich, Alicja Ankarcrona, primo voto Badeni, secundo voto Habsburg, nosząca też tytuł księżnej von Altenburg - aktywna w konspiracji podczas drugiej wojny światowej, członek ZWZ i AK, do końca życia uczuciowo związana z Polską? Pierworodny syn Alicji, Kazimierz Badeni (znany jako dominikanin pod imieniem Joachim) deklarował, że jest 101\% Polakiem, choć, znając go trochę, nie wykluczyłbym z jego strony ironii i przekory. Biografów, wcale licznych, miał już za życia i prowadził z nimi dość osobliwy dialog.

4 Rozmowę z Kazimierzem Narutowiczem opisałem w: W. Łazuga, Okiem stańczyka, Poznań 2018, s. 37-44.

5 W. Łazuga, Rudolf Virchow i rodzinny Świdwin, [w:] tegoż, Okiem stańczyka, s. 68-82.

6 R. von Thadden, Trzygłów. Z dziejów życia na Pomorzu między Kościołem a polityka 1807-1948, przedmowa J.M. Piskorski, tłum. A. Wziątek, Poznań 2015. Dodajmy, że na cmentarzu w Trzygłowie spoczywa Maria von Blanckenburg z domu Thadden-Trieglaff, największa miłość Ottona von Bismarcka. 
Konwersji i rewokacji dokonują ludzie szczerzy i nieszczerzy. Z rozmaitych, nieraz niemożliwych do ustalenia pobudek. Porzucają swą tożsamość i do niej nieraz kilkakrotnie wracają. Dzielą swą tożsamość (swoje ego?) na pół lub na kawałki. Szeptycki z pewnością nie był tu wyjątkiem i kilkakrotnie oznajmiał, że czuje się Polakiem i Rusinem, ale „bardziej Rusinem”, co nie znaczy jeszcze, że nie bywało też odwrotnie. Wspomniane „czucie” pojawia się nieraz jako pochodna reminiscencji, nastrojów, obrazów, zapachów czy kolorów. Bywa zaskakujące nawet dla osoby, która je przeżywa. Dotyczy ruchu w obie strony. I jest doświadczeniem przeważnie mało zależnym od rozumu, a nieraz także woli. Przykładów mamy wiele. Od austriackości (niemieckości?) do polskości powrócili po latach: Jerzy Mycielski, który stał się miłośnikiem legionów i Karol Lanckoroński (ożeniony z Prusaczką), który w niemieckim domu wychowywal swe dzieci na polskich patriotów ${ }^{7}$. W przeciwnym kierunku podążali - żeby pozostać tylko na obszarze c.k. monarchii - Stanisław Madeyski, Florian Ziemiałkowski czy Leon Sapieha coraz silniej utożsamiający się z monarchią habsburską. O falującym poczuciu narodowości możemy mówić w wypadku namiestnika Czech i premiera Austrii Franza (Frantiska) Thuna. Najpierw Czesi mieli go za Niemca. Potem Niemcy za Czecha. Z obu stron słyszał ciężki zarzut zdrady. I niejednokrotnie miał z tym kłopot. Znajdujący się w niemal identycznej sytuacji Heinrich hr. Clam-Martinic, piszący swe nazwisko w dwóch wersjach językowych, oświadczył kiedyś, przecinając spekulacje: „Nie jestem Niemcem i muszę dodać od razu: nie jestem Czechem. Jestem dobrym Austriakiem”. O „austriackości” ekscelencji Leona Bilińskiego, wielokrotnego c.k. ministra skarbu, który w gabinecie Paderewskiego w niepodległej Polsce objął skarb, przekonany był Stanisław Cat-Mackiewicz' ${ }^{9}$. We wspomnieniach Ernsta Trosta „austriackość” dotyczy już nie tylko ludzi, ale całych pokoleń urodzonych pod berłem cesarza Franciszka Józefa ${ }^{10}$. O polskość gen. Colarda, namiestnika Galicji podczas pierwszej wojny światowej, świetnie mówiącego po polsku, nie raz i nie dwa spierali się Polacy. Bywali c.k. generałowie, którzy w rubryce narodowość, mając do wyboru ich jedenaście, tyle bowiem oficjalnie wymieniano w ewidencjach monarchii, wpisywali „inna”. O niektórych mieszkańcach „Kakanii”, mimo wysiłków, nie umiano powiedzieć, kim są. Był

7 W. Łazuga, Kalkulować... Polacy na szczytach c. k. monarchii, Poznań 2013, s. 33, 34.

8 F. Höglinger, Ministerpräsident Heinrich Graf Clam-Martinic, Graz-Köln 1964, s. 224.

9 S. Cat-Mackiewicz, Kto mnie wołat, czego chciat, Warszawa 1972, s. 16.

10 E. Trost, Das blieb vom Doppeladler, Wien-München 1966. 
baron Erb, językowy fenomen władający podobno wszystkimi językami monarchii i byli, wcale liczni, niewładający dobrze żadnym.

Stawiając w centrum zagadnienie identyfikacji narodowej Szeptyckiego znalazła się więc Magdalena Nowak w modnym dzisiaj nurcie badań. Przygotowywała się do nich starannie. Zgromadziła imponujący materiał, zbadała obfite archiwalia rozproszone w dziesięciu archiwach polskich, ukraińskich i austriackich i siedmiu bibliotekach, uwzględniła też zbiory publiczne i prywatne, źródła drukowane i rękopiśmienne rozmaitej proweniencji. Dołożyła do tego bogaty zestaw źródeł drukowanych - blisko trzydzieści tytułów prasowych w kilku językach i kilkadziesiąt różnego rodzaju sprawozdań, szematyzmów i obszernych protokołów parlamentarnych. Lista wspomnień i pamiętników polskich, ukraińskich i austriackich zajmuje bite dwie strony, wykaz literatury przedmiotu - ponad trzydzieści stron. Tyleż mniej więcej liczy wstęp awizujący, co znajdziemy w siedmiu rozdziałach, prawie siedemdziesięciu podrozdziałach, epilogu, zakończeniu i bibliografii pomieszczonych na 613 stronicach dzieła. Z czego - na oko - blisko sto zajmują rozbudowane i spiętrzone wysoko przypisy. A w nich delikatne polemiki, biogramy (nie jestem pewien, czy potrzebne) komentarze (niekonieczne), wyjaśnienia (nieraz zbędne) i rozmaite popisy erudycyjne (budzące uznanie). Uznanie też budzą autorskie przekłady z języka ukraińskiego na polski. Jak zresztą cała bogata filologiczna strona pracy.

Niewątpliwie książka M. Nowak jest osiągnięciem naukowym, świadectwem dojrzałości naukowej Autorki, badawczego talentu, pasji i entuzjazmu. Jest też ekspozycją dojrzałego warsztatu, a jednocześnie - trzeba to powiedzieć - badawczych lęków i zahamowań, przesadnej nieraz ostrożności, asekuracji i reasekuracji. Od Autorki o pokaźnym przecież dorobku naukowym oczekiwałbym większej odwagi i stanowczości. Głębszych cięć materiału i odważniejszych redukcji. Nie pisze wszak dla tzw. „publiczności czytającej”, co teraz dopiero zrobić powinna, lecz do ludzi z tzw. branży. Po co więc objaśnienia, kto był kim w c.k. monarchii, gdy chodzi o nazwiska powszechnie znane, po co długie wstępy i autonomiczne szkice historyczne, polegające $w$ istocie na powtarzaniu powszechnie znanych informacji, po co widoczna w przypisach na każdym kroku staranna troska, aby każdy, kto choć raz coś kiedyś na temat Galicji napisał, mógł odnaleźć siebie i poczuć satysfakcję. Wiem, że tak „politycznie” się dzisiaj pisze - Autorki za to nie winię. Winię przede wszystkim potencjalnych recenzentów, którzy takie obawy u autorów mogą budzić, a także pewien typ „kultury recenzenckiej”, mogący na drodze awansowej młodszych badaczy do takich decyzji skłaniać. Czyż największym winowajcą nie jest zbytni formalizm podejścia i światło uwagi skupione głównie na warsztacie?! Skąd biorą się 
te masowe dezercje z bibliografii rozumowanej i konkluzje książek nerwowo trzymane na uwięzi? Czy naprawdę neutralnej informacji wyłuskanej z tła opowieści, że Gautsch kilkakrotnie był austriackim ministrem (s. 116), należy się odwołanie, a już zwłaszcza do... encyklopedii brytyjskiej. Czy niewinną informację o Uniwersytecie Jagiellońskim (że studia prawnicze na UJ miały charakter zawodowy) trzeba koniecznie podstemplować angielską wersją opracowania trójki krakowskich autorów (s. 135)? Czy pisząc ogólnie o gabinetach austriackich, trzeba zamieszczać przypis do książki J. Buszki traktującej o Polakach w parlamencie wiedeńskim (s. 327)? Czy potrzebne są tak szerokie opisy życia politycznego Galicji, monarchii habsburskiej, a nawet tła europejskiego wypadków? Czy nie prościej byłoby odesłać do obfitej już literatury przedmiotu poświęconej gimnazjum św. Anny w Krakowie, zamiast wdawać się w dość szczegółowy opis? Zwłaszcza, że zbytnie nagromadzenie informacji odbiera narracji powietrza. Nie powinniśmy też zbyt długo czekać na powrót bohatera i główny nurt tej rzeki. Autorka, antycypując odczucia czytelnika, zapowiada wprawdzie, że do jakiegoś wątku jeszcze nawiąże lub powróci, ale świadomie lub nieświadomie dokonuje w istocie powtórek. No i nieraz, chcąc powiedzieć za dużo, w tym gąszczu się gubi. I tak, to nie Kraków, lecz Galicja była „polskim Piemontem” (s. 108). Szeptycki nie mógł być zwolennikiem poglądów Grocholskiego (s. 327), bo Grocholski wywierał wprawdzie spory wpływ na wielu współczesnych (skądinąd jako prezes Koła na samego ex-rektora i późniejszego wielokrotnego ministra, Leona Bilińskiego), ale z poglądami akurat niewiele miało to wspólnego. To samo w zasadzie mógłbym powiedzieć o Apolinarym Jaworskim, którego nikt za źródło opinii nie uważał. To samo wreszcie o ministrze do spraw Galicji, Adamie Jędrzejowiczu, którego udział w nominacji Szeptyckiego był według wszelkiego prawdopodobieństwa minimalny. Ministerium do spraw Galicji - udowodnił to Damian Szymczak - znaczyło w istocie tyle, ile osoba piastująca ten urząd ${ }^{11}$. A Jędrzejowicz. zasłużony dla Rzeszowszczyzny, do koryfeuszy w tym gronie z pewnością nie należał.

W sprawie namiestnika Leona hr. Pinińskiego (s. 333) rację - moim zdaniem mają cytowani historycy ukraińscy, z którymi Autorka ciekawie polemizuje. Mówiąc ściślej: Pinińskiego profesora, subtelnego intelektualistę, „wagnerzystę i fauścistę”, omnibusa, poliglotę i estetę od Pinińskiego polityka mającego organiczny problem z określeniem stosunku do Ukraińców trzeba wyraźnie oddzielić. Nie był przychylny ani Szeptyckiemu, ani Bobrzyńskiemu, ani jeszcze wcześniej Badeniemu, bo z trud-

11 D. Szymczak, Galicyjska „ambasada” w Wiedniu. Dzieje ministerstwa dla Galicji 1871-1918, Poznań 2013. 
ną do wyjaśnienia konsekwencją krytykował i podawał w wątpliwość każdą próbę porozumienia Polaków z Ukraińcami. To zresztą jedna z najbardziej tajemniczych i fascynujących postaci galicyjskiego areopagu, która wciąż czeka na swego biografa. Złożona z miękkości i twardości, z delikatności, którą tak podziwiała związana z nim blisko Karolina Lanckorońska, i brutalności, którą zaskakiwał nie tylko wrogów, ale i przyjaciół. Prawdziwy sfinks.

Informacja o Bilińskim (s. 439) właściwie poprawna, choć nie najlepiej sformułowana. Historyka politycznego Galicji musi zastanowić zdanie: „W czasie I wojny światowej i walk o granice państwa stał na czele Naczelnego Komitetu Narodowego". Owszem, stał, ale dopiero wtedy, kiedy po ustąpieniu Lea i Jaworskiego NKN tracił na znaczeniu. Jeszcze związane z tym pytanie do Autorki: do kiedy - jej zdaniem wspomniana walka o granice trwała?

Z punktu widzenia celów pracy nie są to uwagi i sprawy pierwszorzędne - raczej uwagi i korekty. Każdego natomiast zaciekawić musi, dlaczego, zdaniem Autorki, dwa „światy” skończyły się w Szeptyckim w 1914 r.? Wszak trochę jeszcze pożył. Czasy nadeszły nie mniej burzliwe i dla tytułowych dwóch światów historia wcale się nie skończyła. Mamy spodziewać się dalszego jej ciągu? Gorąco bym Autorkę namawiał.

Pierwszorzędne są w książce partie poświęcone „przemianom” tożsamości narodowej Szeptyckiego - procesowi z rozmaitymi meandrami, spowolnieniami i przyspieszeniami. Sporo tu ciekawego materiału, badawczego entuzjazmu, świetnego opanowania źródeł i literatury, osobliwie ukraińskiej. Bardzo przypadł mi go gustu rozbudowany wątek jezuicki biografii - przyznaję, że nie dostrzegałem go w takiej skali. Reforma dobromilska, jezuicki spowiednik i mentor matki i syna, coraz większa religijność matki („hrabiny mniej lub bardziej dobroczynnej”), jezuickie ambicje na wschodzie, jezuiccy bazylianie. Rola w tym dziele Henryka Jackowskiego, krakowskiego rektora i prowincjała zakonu, któremu Watykan zlecił misję reformy bazylianów. I nader dla Szeptyckiego znamienne ambicje krzewienia oświaty nie dla niej samej, lecz by świat będący „stugłową hydrą” zanadto się nie zmienił, bo gdy się zmieni, to się wykolei. Niebezpieczeństwo dostrzegał ze strony modernizującego się społeczeństwa, rozwijającego się kapitalizmu, finansjery i idei liberalnej. Mamy tu pogłębiającą się religijność i twardniejący stopniowo konserwatyzm. Z mentorów poza Jackowskim (dobrze nakreślono jego relacje z całą właściwie rodziną) wymienić trzeba przede wszystkim hieratycznego Pawła Popiela, natchnienie kilku pokoleń zachowawców. Dobrze przedstawiono całą bliższą ciału część biografii metropolity (choć opis choroby i rekonwalescencji zajmujący kilkanaście stronic, s. 272-285, to 
jednak gruba profuzja). Dobrze skreślono całe to teologiczne wykształcenie i jezuickie sumienie bohatera, który w 1905 r. już z brodą wyrusza z pielgrzymką do Ziemi Świętej. Ciekawie opisano jego zmienne relacje z ojcem (od potępienia przez ojca fanatyzmu Romana po „niegodnym syna”) i - w innym już planie - wpływ jezuitów na unię brzeską i nigdy właściwie niewygasłe ambicje nawrócenia Rosji (s. 224). Do jezuickiego „racjonalizmu” - zdaniem M. Nowak - dodał Szeptycki pewien rodzaj romantyzmu wsparty argumentem „starożytnej” genealogii stanowiącej rodzaj zobowiązania. Kto wie, czy nie są to najważniejsze myśli tej monografii. Może to bowiem z takich właśnie przesłanek i wątków, w takim ordynku wynikało coraz silniejsze poczucie posłannictwa i życiowej misji, dając dziwne połączenie realizmu z mistycyzmem. Może to tu właśnie należy szukać klucza do Szeptyckiego i wszystkich jego ideowych i duchowych metamorfoz. Już w dzieciństwie miała go charakteryzować delikatność, pobożność i „anielska dobroć”, a obok tego „niezmierna determinacja”, upór, rycerskość i zamiłowanie do wojskowego rzemiosła. Idealizując obraz syna, pisała Zofia, że posiadał on charakter nacechowany „dziwnie uroczą sprzecznością” (s. 86), co - dodajmy - jest niemal kompletnym zestawem walorów stwierdzanych u młodzieńców podążających za Ignacym Loyolą - owych Don Kichotów „w boskim stylu”" ${ }^{\prime 2}$. Wybór narodowości - z czasem problem centralny - mógł być wtedy łatwiejszy i mniej kosztowny niż się to wydaje. W szkole i na studiach Szeptycki w odpowiedniej rubryce wpisywał: Polak. Ukraińcem (Rusinem) poczuł się, przebywając... we Wrocławiu [sic - W.Ł.]. Potem raz był bardziej jednym, raz drugim, gdy jego nowi pobratymcy - pisze Andrew Wilson - dopiero około 1900 r. stawali się Ukraińcami, choć trudno ustalić dynamikę tego procesu ${ }^{13}$. Wielonarodowościowy kosmos c.k. monarchii, a także pospolicie występujące obok siebie rozmaite odmiany „austriackich” i „,rzymskich” mieszanek nie rozjaśniają obrazu. Już sama wielojęzyczność (multilingwizm) oznaczała pewien rodzaj „austriackości” (im więcej znasz języków, tym lepszym jesteś Austriakiem ${ }^{14}$. Nie wszystkie kontury naszego bohatera muszą być więc ostre. Nie wszystkie rysy jednoznaczne. Nie wszystko da się (i koniecznie trzeba) wtłaczać do zawczasu przygotowanych szuflad. Ostrość ani szuflada nie są domeną tamtego, minionego dawno świata. Monarchia habsburska po rezygnacji z oświeceniowych ambicji unifikacyjnych Józefa II była nie tylko miękkim,

12 J.I. Tellechea Idigoras, Ignacy Loyola. Sam i na piechotę, tłum. K. Jachimska-Małkiewicz, Kraków 2014.

13 A. Wilson, Ukraińcy, tłum. M. Urbański, Warszawa 2002, s. 111.

14 P.M. Judson, Imperium Habsburgów. Wspólnota narodów, thum. S. Patlewicz, Warszawa 2017, s. 239. 
liberalnym imperium narodów, ale i miękkim, liberalnym, bogatym w rozmaite typy ludzkie imperium biograficznym.

Autorka kropki nie stawia. Zamyka książkę na 1914 r., kończy opowieść przed pokojem brzeskim, który wstrząsnął galicyjskim austrofilizmem, przed ostatecznym rozpadem tamtego świata.

Czekamy na dalszy ciąg tej fascynującej opowieści.

Nikt Autorki w tym dziele wyręczać nie powinien.

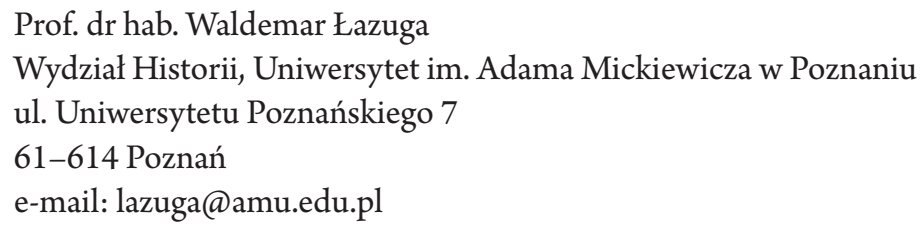

\section{Bibliografia/Bibliography}

Cat-Mackiewicz S., Kto mnie wołat, czego chciat, Warszawa 1972

Höglinger F., Ministerpräsident Heinrich Graf Clam-Martinic, Graz-Köln 1964

Judson P.M., Imperium Habsburgów. Wspólnota narodów, tłum. S. Patlewicz, Warszawa 2017

Kłoskowska A., Kultury narodowe u korzeni, Warszawa 1996

Łazuga W., Kalkulować... Polacy na szczytach c. k. monarchii, Poznań 2013

Łazuga W., Okiem stańczyka, Poznań 2018

Nowak M., Szeptycki Roman, w zakonie Andrzej, [w: ] PSB, t. 48/2, Warszawa-Kraków 2012, s. 216-224

Szeptycka z Fredrów Z., Młodość i powołanie ojca Romana Andrzeja Szeptyckiego zakonu św. Bazylego Wielkiego opowiedziane przez matkę jego 1865-1892, oprac. B. Zakrzewski, Wrocław 1993

Szymczak D., Galicyjska „ambasada” w Wiedniu. Dzieje ministerstwa dla Galicji 1871-1918, Poznań 2013

Tellechea Idigoras J.I., Ignacy Loyola. Sam i na piechotę, tłum. K. Jachimska-Małkiewicz, Kraków 2014

Thadden R. von, Trzygłów. $Z$ dziejów życia na Pomorzu miedzy Kościotem a polityka 1807-1948, przedmowa J.M. Piskorski, tłum. A. Wziątek, Poznań 2015

Trost E., Das blieb vom Doppeladler, Wien-München 1966

Wilson A., Ukraińcy, thum. M. Urbański, Warszawa 2002 